\title{
CNBP Gene
}

National Cancer Institute

\section{Source}

National Cancer Institute. CNBP Gene. NCI Thesaurus. Code C97888.

This gene is involved in sterol-mediated transcription. 